\title{
PENGARUH WARNA WADAH BERBEDA TERHADAP PERTUMBUHAN NANNOCHLOROPSIS SP
}

\author{
The Effect of Different Container Colors on the Growth of Nannochloropsis sp. \\ Nur Achmad Saputra ${ }^{1}$, A. Gusti Tantu ${ }^{2}$, Machuluddin Amin ${ }^{3}$, Dahlifa $^{2}$, Sutia Budi ${ }^{2}$ \\ ${ }^{1}$ Jurusan Perikanan, Universitas Bosowa \\ ${ }^{2}$ Program Studi Budidaya Perairan Fakultas Pertanian Universitas Bosowa \\ ${ }^{3}$ Pengembangan Budidaya Air Payau (BPPBAP), Kabupaten Maros
}

Email : saputra12@gmail.com

Diterima: 03 Juli 2020

Dipublikasikan: 05 Desember 2020

\begin{abstract}
ABSTRAK
Pertumbuhan fitoplankton dipengaruhi oleh beberapa faktor fisika seperti suhu, cahaya matahari, kedalaman, kekeruhan, salinitas, dan kandungan oksigen, faktor kimia seperti $\mathrm{pH}$, fosfat, nitrat, nitrit, dan silikat serta warna wadah kultur. Tujuan penelitian untuk mengetahui pengaruh warna wadah terhadap pertumbuhan Nanochloropsis sp. Penelitian didesain menggunakan Rencana Acak Lengkap (RAL). Perlakuan yang diuji adalah penggunaan wadah kultur yang memiliki warna berbeda dengan empat perlakuan dan tiga kali ulangan. Warna wadah yang digunakan adalah merah, kuning, biru dan bening. Hasil penelitian menunjukkan penggunaan warna wadah berpengaruh nyata terhadap pertumbuhan Nannochloropsis sp. Warna wadah terbaik untuk pertumbuhan Nannochloropsis sp. adalah bening.
\end{abstract}

Kata Kunci: Nannochloropsis, Warna, Wadah Kultur, Pertumbuhan

\section{ABSTRACT}

Phytoplankton growth is influenced by several physical factors such as temperature, sunlight, depth, turbidity, salinity, and oxygen content, chemical factors such as $\mathrm{pH}$, phosphate, nitrate, nitrite, and silicate as well as the color of the culture container. The purpose of the study was to determine the effect of container color on the growth of Nanochloropsis sp. The study was designed using a Completely Randomized Plan (CRD). The treatment tested was the use of culture containers that had different colors with four treatments and three replications. The color of the container used is red, yellow, blue and clear. The results showed that the use of container color significantly affected the growth of Nannochloropsis sp. The best container color for the growth of Nannochloropsis sp. is clear.

Keywords: Nannochloropsis, Color, Culture Container, Growth

\section{PENDAHULUAN}

Plankton merupakan pakan alami yang sangat penting dalam proses budidaya ikan. Plankton adalah faktor penunjang pertumbuhan dan kelangsungan hidup organisme yang dibudidayakan khususnya pada fase larva atau benih. Hal ini disebabkan karena ukuran plankton yang sangat kecil sesuai dengan bukaan mulut larva ikan. Menurut Nontji (2008), plankton adalah mahluk (tumbuhan atau hewan) yang hidupnya mengapung, mengambang, atau melayang di dalam air yang kemampuan renangnya (kalaupun ada) sangat terbatas hingga selalu hanyut terbawa oleh arus. Secara fungsional, plankton dapat digolongkan menjadi empat golongan utama, yakni fitoplankton, zooplankton, bakterioplankton, dan virioplankton.

Fitoplankton atau yang juga biasa disebut mikrolga merupakan plankton tumbuhan. Menurut Zhumaritha (2011), mikroalga merupakan mikroorganisme prokariotik atau eukariotik yang dapat berfotosintesis dan dapat tumbuh cepat pada kondisi yang sulit. Fitoplankton dapat digunakan sebagai pakan pada larva ikan atau zooplankton seperti rotifer dan artemia (Budi et al, 2011; Budi \& Khairuddin, 2012; Faidar et $a l, 2020)$. Salah satu pengembangan budidaya pakan alami adalah fitoplankton dari kelas Eustigmatophyceae yaitu Nannochloropsis sp (Budi et al. 2018).

Pertumbuhan Nannochloropsis sp., seperti halnya fitoplankton lainnya, dipengaruhi oleh banyak faktor. Menurut Merizawati (2008), pertumbuhan fitoplankton dipengaruhi oleh beberapa faktor fisika seperti suhu, cahaya matahari, kedalaman, kekeruhan, salinitas, dan kandungan oksigen; faktor kimia seperti $\mathrm{pH}$, fosfat, nitrat, nitrit, dan silikat.

Cahaya matahari diperlukan oleh setiap tumbuhan untuk proses fotosintesis. Proses fotosintesis terjadi karena adanya zat hijau daun atau kloroplas. Kandungan klorofil di dalam kloroplas pada beberapa tumbuhan memiliki perbedaan. Untuk Nannochloropsis SP., klorplasnya hanya mengandung klorofil a, seperti yang dikemukakan oleh Zhumaritha (2011) bahwa, Nannochloropsis sp. memiliki satu atau lebih plastid berwarna hijau kuning yang mengandung klorofil a, tidak mengandung klorofil b. Menurut Furqonita (200--), Klorofi a mengandung warna hijau dan mempunyai rumus molekul $\mathrm{C}_{55} \mathrm{H}_{72} \mathrm{MgN}_{4} \mathrm{O}_{6}$ sedangkan klorofil $\mathrm{b}$ mengandung warna biru dan mempunyai rumus molekul $\mathrm{C}_{55} \mathrm{H}_{70} \mathrm{MgN}_{4} \mathrm{O}_{6}$. Wulandari (2011), fotosintesa merupakan proses perubahan senyawa anorganik menjadi senyawa organik dengan bantuan cahaya matahari. Faktor utama yang mempengaruhi fotosintesis adalah kandungan 
klorofil yang dimiliki oleh tanaman. Klorofil terdapat sebagai butir-butir dalam kloroplast yang terdapat pada stroma dan tilakoid. Butir-butir yang terdapat di dalamnya disebut grana. Pada tanaman tingkat tinggi ada dua macam klorofil utama yang ikut dalam proses fotosintesis, klorofilnya yaitu : (1) klorofil $\mathrm{a}=\mathrm{C}_{55} \mathrm{H}_{72} \mathrm{O}_{5} \mathrm{~N}_{4} \mathrm{Mg}$ dan (2) klorofil $\mathrm{b}=$ $\mathrm{C}_{55} \mathrm{H}_{70} \mathrm{O}_{6} \mathrm{~N}_{4} \mathrm{Mg}$. Menurut Furqonita (2000), umumnya terdapat dua macam klorofil, yaitu klorofil a dan klorofil b. Klorofil a mengandung warna hijau dengan rumus molekul $\mathrm{C}_{55} \mathrm{H}_{72} \mathrm{MgN}_{4} \mathrm{O}_{3}$ sedangkan klorofil b mengandung warna biru dan mempunyai rumus molekul $\mathrm{C}_{55} \mathrm{H}_{70} \mathrm{MgN}_{4} \mathrm{O}_{6}$. Klorofil berfungsi untuk menyerap energi cahaya matahari selain warna hijau.

Tiap atom atau molekul sedikit berbeda tingkat energinya, setiap substansi menyerap cahaya dengan suatu karakteristik panjang gelombang yang berbeda. Hal ini bisa ditunjukkan melalui spektrum penyerapan, dimana ditujukan selama penyerapan sinar pada tiap gelombangnya, sebagai contoh, klorofil a sangat kuat pada panjang gelombang $660 \mathrm{~nm}$ pada sinar merah, dan paling rendah pada panjang gelombang 430 nm pada sinar biru (wulandari, 2011).

Spektrum absorbsi klorofil a dan klorofil b berbeda. Cahaya yang tidak cukup absorbsi oleh klorfil a pada panjang gelombang $460 \mathrm{~nm}$ akan ditangkap oleh klorofil b yang mempunayi absorbsi yang kuat pada panjang gelombang tersebut. Jadi kedua jenis klorofil ini saling melengkapi dalam mengabsorbsikan cahaya matahari. Daerah spektrum antara $500 \mathrm{~nm}$ dan $600 \mathrm{~nm}$ sangat lemah absorbsi oleh klorofil, tetapi hal demikian tidak menjadi masalah bagi kebanyakkan tanaman hijau (Wulandari, 2011).

Berdasarkan hal tersebut, dapat diambil sebuah hipotesis bahwa agar fotosintesis terjadi, cahaya yang diterima harus berupa warna yang sesuai. Untuk itu dilakukan sebuah penelitian tentang pengaruh warna wadah terhadap pertumbuhan Nanochloropsis sp.

\section{METODE PENELITIAN}

\section{Tempat dan Waktu}

Penelitian ini dilaksanakan di Balai Penelitian dan Pengembangan Budidaya Air Payau (BPPBAP), Kabupaten Maros, Sulawesi Selatan.

\section{Bahan dan Peralatan Penelitian}

Alat yang akan digunakan terlebih dahulu dicuci menggunakan detergen hingga bersih dan dibilas dengan aquades. Alat yang telah bersih kemudian disterikan dengan cara dimasukkan ke dalam oven dengan suhu $90{ }^{\circ} \mathrm{C}$. Alat-alat tersebut kemudian dirangkai sesuai dengan rancangan yang telah ditentukan. Untuk jarak toples ke lampu diatur sedemikian rupa hingga mendapatkan intensitas cahaya yang sama. Setelah itu, masing-masing toples diberi selang aerasi.

Bibit Nannochloropsis sp. yang digunakan merupakan kultur murni yang diperoleh dari hasil biakan di Balai Penelitian dan Pengembangan Budidaya Air Payau. Sebelum ditebar, bibit tersebut terlebih dahulu dihitung kepadatannya dengan menggunakan hemachytometer dan bantuan mikroskop.

\section{Metode penelitian}

Media kultur yang digunakan adalah air laut. Air laut yang telah tertampung disaring dengan filter bag dan ditampung kembali. Air laut yang telah disaring kemudian disterilkan dengan menggunakan autoclove dan dimasukkan ke dalam wadah penampungan.

Setelah air laut steril, air laut tersebut dimasukkan ke dalam toples masing-masing sebanyak 21 . Kemudian diberi pupuk conway sebanyak $2 \mathrm{ml} / \mathrm{l}$ media, serta vitamin mix sebanyak 1 tetes/l. setelah itu media diaduk agar pupuk dan vitamin tercampur dengan rata.

Pipet bibit Nannochloropsis sp. ke dalam toples berisi media dengan volume sesuai dengan hasil perhitungan pengenceran. Setelah itu tutup wadah dan nyalakan aerasi.

Perawatan kultur meliputi pengawasan pencahayaan, suhu dan aerasi. Pengamatan populasi Nannochloropsis sp. dilakukan dengan menghitung kepadatan Nannochloropsis sp. yang dilakukan setiap hari sekali. Kepadatan populasi dihitung dengan menggunakan alat Hemacytometer dengan bantuan mikroskop dan Hand Counter.

Penelitian didesain menggunakan Rencana Acak Lengkap (RAL). Perlakuan yang diuji adalah penggunaan wadah kultur yang memiliki warna berbeda dengan empat perlakuan dan tiga kali ulangan. Warna wadah yang digunakan adalah merah, kuning, biru dan bening.

\section{Parameter Uji}

\section{Pertumbuhan Populasi/Kepadatan}

Pengamatan kepadatan Nannochloropsis sp. dilakukan sampai kelimpahan Nannochloropsis sp. cenderung stabil atau sampai air dalam akuarium pengamatan berubah warna dari jernih menjadi sangat hijau. Kelimpahan fitoplankton (Nannochloropsis sp.) dapat dihitung menggunakan rumus sebagai berikut:

$$
N=\frac{n}{4} \times 10^{4}
$$

Keterangan

$\mathrm{N}=$ Kelimpahan individu (sel $/ \mathrm{ml})$

$\mathrm{n}=$ Jumlah sel

$10^{-4}=$ Volume air sampel yang menutupi 1 kotak besar pada haemacytometer $(\mathrm{ml})$

\section{Laju Pertumbuhan Sel}

Laju pertumbuhan sel dapat dihitung dengan menggunakan rumus (Amini dan Sugiyono, 2008)

Keterangan:

$$
k=\frac{\log 10 \mathrm{~N} / \mathrm{N0}}{T-T 0} \times 3.22
$$

- $\quad \mathrm{k}$ adalah laju pertumbuhan

- $\quad \mathrm{N}$ adalah jumlah sel pada waktu T dan

- No adalah jumlah sel awal

- $\quad$ nilai 3,22 merupakan faktor koreksi.

\section{Analisa Data}

Untuk mengetahui pengaruh warna wadah terhadap pertumbuhan Nannochloropsis Sp., maka data yang diperoleh selama penelitian dianalisis dengan menggunakan sidik ragam (ANOVA). Apabila hasil analisis terbukti bahwa perlakuan berpengaruh nyata akan dilanjutkan dengan uji BNT untuk menentukan perlakuan yang menghasilkan respon terbaik. 
Sebagai alat bantu yang digunakan yaitu SPSS versi 16 for windows. Untuk menyajikan grafik dan tabulasi data menggunakan Microsoft exel 2007.

\section{HASIL DAN PEMBAHASAN}

\section{Pertumbuhan Populasi Nannochloropsis sp}

Hasil penelitian, pertumbuhan populasi/kepadatan Nannochloropsis sp. pada masing-masing wadah kultur memperlihatkan hasil yang berbeda-beda. Nannochloropsis merupakan sel berwarna kehijauan, tidak motil, dan tidak berflagel. Selnya berbentuk bola, berukuran kecil dengan diamater 4-6 $\mu \mathrm{m}$. Organisme ini merupakan divisi yang terpisah dari Nannochloris karena tidak adanya chlorophyl b, merupakan pakan yang populer untuk rotifer, artemia, dan pada umumnya merupakan organisme filter feeder (penyaring) (Wiguna, 2009). Kepadatan rata-rata tertinggi dicapai pada perlakuan D, yaitu wadah berwarna bening, kemudian $\mathrm{C}$ (biru), B (kuning) dan A (merah). Grafik pertumbuhan populasi/kepadatan Nannochloropsis sp. pada masing-masing perlakuan dapat dilihat pada Gambar 1.

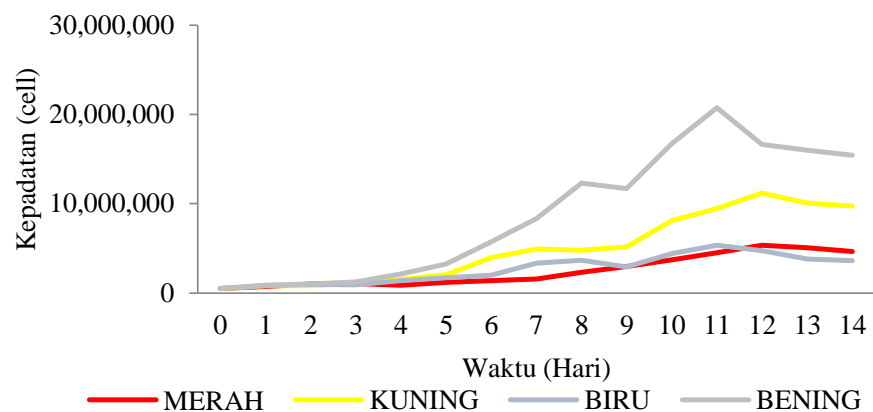

Gambar 1. Grafik pertumbuhan populasi/kepadatan Nannochloropsis sp.

Gambar 1 menunjukkan pertumbuhan Nannochloropsis sp. selama 14 hari. Pada awal pemeliharaan, kepadatan Nannochloropsis sp. Masih rendah, kemudian mulai meningkat pada hari berikutnya hingga akhirnya perlakuan D (bening) mengalami puncak pertumbuhan pada hari ke 11 dengan kepadatan rata-rata mencapai $2,07 \times 10^{7}$. Sementara perlakuan lainnya mencapai puncak kepadatan pada hari ke 12 dengan kepadatan rata-rata masing-masing A: $5,36 \times 10^{6}$, B: $1,12 \times 10^{7}$ dan $C: 4,73 \times 10^{6}$. Berdasarkan hasil tersebut dapat diketahui bahwa perlakuan terbaik adalah perlakuan D dengan wadah berwarna bening.

Hasil analisis ragam menunjukkan bahwa perlakuan warna wadah yang berbeda memberikan pengaruh nyata terhadap pertumbuhan populasi/kepadatan Nannochloropsis sp. Setelah dilakukan uji lanjut dengan uji Tukey, diketahui bahwa perlakuan D (wadah bening) memiliki perbedaan yang cukup signifikan terhadap semua perlakuan lainnya.

Telah diketahui bahwa ada beberapa faktor yang dapat mempengaruhi pertumbuhan Nannochloropsis sp., salah satunya adalah cahaya. Cahaya matahari berperan dalam proses fotosintesis, seperti yang dikemukakan oleh Meutya (2011), bahwa cahaya sangat mempengaruhi kecepatan fotosintesis, makin tinggi intensitas cahaya maka fotosintesis makin cepat maka, untuk mendapatkan hasil fotosintesis yang maksimum diusahakan semua bagian daun kena cahaya matahari. Bila tak ada cahaya maka proses fotosintesis tak akan berlangung. Energi cahaya matahari yang dibutuhkan pada fotosintesis diserap oleh sel hijau daun yang disebut klorofil.

Telah diketahui pula bahwa, Nannoclhoropsis sp tidak mengandung klorofil, seperti yang diungkapakan oleh Zumaritha, 2011, bahwa Nannochloropsis sp. memiliki satu atau lebih plastid berwarna hijau kuning yang mengandung klorofil a tidak mengandung klorofil b. Violaxanthin merupakan pigmen tambahan yang berfungsi membantu dalam penyerapan cahaya.

Menurut anonim (2010) klorofil a terutama menyerap cahaya biru-violet dan merah. Klorofil b menyerap cahaya biru dan oranye dan memantulkan cahaya kuning-hijau. Hal ini berarti bahwa Nannoclhoropsis sp. akan lebih cenderung menyerap warna biru dan merah. Namun berdasarkan hasil penelitian yang telah dilaksanakan, kepadatan tertinggi diperoleh dari perlakuan $\mathrm{D}$ yaitu menggunakan wadah bening. Hal ini mungkin disebabkan karena wadah bening akan meneruskan seluruh atau sebagian besar spektrum cahaya, termasuk biru dan merah sehingga Nannochloropsis sp. bisa tumbuh dengan baik, berbeda dengan wadah berwarna lain yang sebagian besar hanya meneruskan spektrum warna dari warna wadahnya. Hal tersebut juga diduga menyebabkan berkurangnya intensitas cahaya yang masuk kedalam wadah dan diterima oleh Nannoclhoropsis sp. sehingga proses fotosintesis tidak berlasung secara maksimal.

\section{Laju Pertumbuhan Nannochloropsis sp.}

Laju pertumbuhan tertinggi pada masing-masing perlakuan diperoleh dari perlakuan D (wadah bening) seperti yang tampak pada gambar 6. Hal tersebut juga didukung oleh hasil analisis keragaman dan uji Tukey yang menunjukkan bahwa terdapat perbedaan yang signifikan antara perlakuan D dengan perlakuan $\mathrm{A}$ dan $\mathrm{C}$ dimana nilai $\mathrm{P}<0,05$. Pada gambar 6 juga dapat dilihat bahwa laju pertumbuhan tertinggi terjadi pada hari pertama. Sementara pada hari ke 10 hingga 14, laju pertumbuhannya cenderung terus menurun.

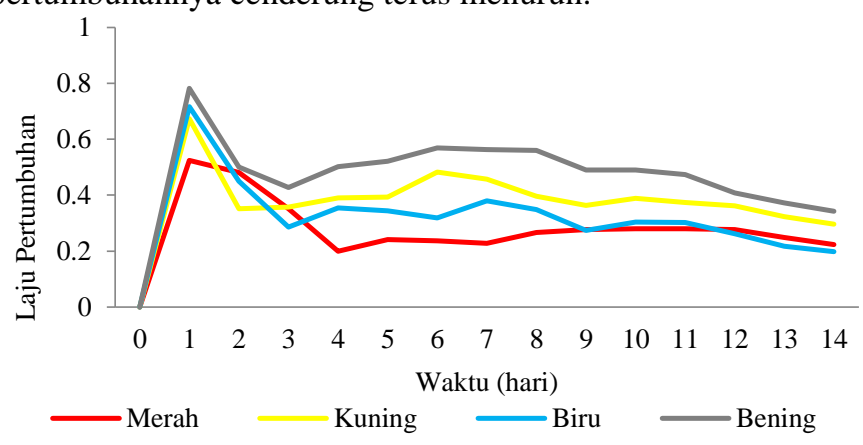

Gambar 2. Grafik Laju pertumbuhan populasi Nannochloropsis sp.

Tingginya laju pertumbuhan Nannochloropsis sp. pada hari pertama ini diperkirakan terjadi karena pada hari pertama, kepadatan sel Nannochloropsis sp. masih rendah, sementara itu nutrisi yang tersedia masih melimpah sehingga Nannochloropsis sp. dapat dapat memanfaatkan nutrisi 
tersebut secara optimal untuk pertumbuhannya. Penurunan kelimpahan sel mikroalga pada hari ke 10 hingga hari ke 14 diduga disebabkan karena kepadatan populasi yang sudah cukup tinggi dan kandungan nutrisi media yang sudah berkurang. Hal ini menyebabkan terjadinya persaingan dan kurangnya asupan nutrisi sehingga banyak sel yang mengalami kematian.

Faktor-faktor yang mempengaruhi pertumbuhan suatu jenis fitoplankton dapat dikelompokkan menjadi faktor internal dan factor eksternal. Faktor internal yang berpengaruh terhadap sifat-sifat pertumbuhan fitoplankton adalah faktor genetik (Meritasari et al, 2010). Faktor eksternal berkaitan dengan kertersedian unsur hara makro dan mikro serta kondisi lingkungan. Faktor-faktor lingkungan yang berpengaruh terhadap pertumbuhan fitoplankton antara lain cahaya, salinitas, suhu, kandungan $\mathrm{O}_{2}$, kandungan $\mathrm{CO}_{2}$ dalam air, dan pH air (Meritasari et al, 2010).

Nannochloropsis sp. bersifat kosmopolit dapat tumbuh pada salinitas 0-35 ppt. salinitas optimum untuk pertumbuhannya adalah $25-35 \mathrm{ppt}$, suhu $25-30^{\circ} \mathrm{C}$ merupakan kisaran suhu yang optimal. Fitoplankton ini dapat tumbuh baik pada kisaran pH 8-9,5 dan intensitas cahaya 100-10000 lux (Nannochloropsis sp. lebih dikenal dengan nama Chlorela laut) (Wiguna, 2009)

\section{KESIMPULAN}

Hasil penelitian dapat disimpulkan bahwa penggunaan warna wadah berpengaruh nyata terhadap pertumbuhan Nannochloropsis sp. Warna wadah terbaik untuk pertumbuhan Nannochloropsis sp. adalah bening. Untuk menghasilkan pertumbuhan yang optimal disaranakan tetap menggunakan wadah bening atau tembus cahaya pada budidaya Nannochloropsis sp. skala laboratorium. Perlu dilakukan penelitian mengenai pengaruh tingkat intensitas cahaya berbeda pada pertumbuhan Nannochloropsis sp.

\section{DAFTAR PUSTAKA}

Amali, T.F.I. 2005. Pengaruh Pemberian Nannochloropsis sp., Natan, dan Coccolith sp. pada Rotifera Terhadap Kelangsungan Hidup dan Pertumbuhan Larva Ikan Kerapu Macan (Epinephelus fuscoguttatus). Fakultas Perikanan dan Ilmu Kelautan, Institut Pertanian Bogor. Bogor.

Amini, S dan Sugiyono. 2008. Penelitian Mikroalgae Laut Jenis Spirulina platensis dan Nannochloropsis sebagai Sumber Biodiesel. Balai Besar Pengolahan Produk dan Bioteknologi Kelautan Perikanan Jakarta. Jakarta.

Anonim. 2010. "Percobaan Laju Fotosintesis". http://biologigonz.blogspot.com/ 2010_07_01_ archive.html. [diakses 3 Maret 2012]

Budi, S., Karim, M. Y., Trijuno, D. D., Nessa, M. N., \& Herlinah, H. (2018). Pengaruh Hormon Ecdyson Terhadap Sintasan Dan Periode Moulting Pada Larva Kepiting Bakau Scylla olivacea. Jurnal Riset Akuakultur, 12(4), 335-339.

Budi, S., \& Aslamsyah, S. (2011). Improvement of the nutritional value and growth of rotifer (Brachionus plicatilis) by different enrichment period with Bacillus sp. Jurnal Akuakultur Indonesia, 10(1), 67-73.

Budi, S., \& Khairuddin, K. (2012, December). Tingkat penerimaan larva udang windu penause monodon terhadap Mikroalga Chaetoceros Gracilis Yang Diberi Berbagai Konsentrasi Karbondioksida. in Prosiding Forum Inovasi Teknologi Akuakultur (pp. 503-508).

Budi, S., \& Jompa, H. (2012, December). Pengaruh Periode Pengkayaan Rotifer Brachionus plicatilis Oleh Bacillus sp. Terhadap Kualitas Asam Amino Esensial. In Prosiding Forum Inovasi Teknologi Akuakultur (pp. 599-603).

Faidar, F., Budi, S., \& Indrawati, E. (2020). Analisis Pemberian Vitamin C Pada Rotifer dan Artemia Terhadap Sintasan, Rasio Rna/Dna, Kecepatan Metamorfosis Dan Ketahanan Stres Larva Rajungan (Portunus Pelagicus) Stadia Zoea. Journal of Aquaculture and Environment, 2(2), 30-34

Furqonita, D. 2000. Seri Ipa Biologi Smp Kelas Viii. Yudhistira Ghalia Indonesia. Jakarta

Meritasari, D, dkk. 2010. Eksplorasi Bahan Aktif Mikroalga Laut Nannochloropsis oculata Sebagai Antibakteri (Penghambat) Vibrio alginolyticus. Universitas Airlangga, Surabaya.

Merizawati. 2008. Analisis Sinar Merah, Hijau, dan Biru (RGB) untuk Mengukur Kelimpahan Fitoplankon (Chlorella sp.). Fakultas Perikanan dan Ilmu Kelautan, Institut Pertanian Bogor. Bogor.

Meutya, D. 2011. "Pigmen fotosintesis". http://dezimeutya.blogspot.com /2011/06/ pigenfotosintesis.html. [diakses 3 Maret 2012]

Nontji, A. 2008. Plankton Laut. Yayasan Obor Indonesia. Jakarta.

Underground, K. M. 2011. "Fermentasi Kotoran Ayam". http://leogendeng. blogspot.com/2011/10/fermentasikotoran-ayam.html. [diakses 9 Mei 2012]

Wiguna, E. $2009 . \quad$ "Nannochloropsis sp.". http://ekawiguna.wordpress.com/ 2009/12/13/nannochloropsis-sp/. [diakses 12 April 2012]

Wulandari, J. 2011. "Fotosintesis dan Pigmen Fotosintesis". http://jeniewulandari. wordpress.com/2011/12/15/fotosintesis/. [diakses 3 Maret 2012]

Zumaritha, F. 2011. Pemanfaatan Karbondioksida $\left(\mathrm{CO}_{2}\right)$ untuk Kultivasi Mikroalga Nannochloropsis sp. Sebagai Bahan Baku Biofuel. Fakultas Perikanan dan Ilmu Kelautan, Institut Pertanian Bogor. Bogor. 